\title{
Cellulase Activities of Some Aerobic Micro-organisms Isolated from Soil
}

\author{
By J. M. LYNCH, ${ }^{1 *}$ J. H. SLATER, ${ }^{2}$ JACQUELINE A. BENNETT ${ }^{1,2}$ \\ AND S. H. T. HARPER ${ }^{1}$ \\ ${ }^{1}$ Agricultural Research Council Letcombe Laboratory, Wantage, Oxon OXI2 9JT, U.K. \\ ${ }^{2}$ Department of Environmental Sciences, University of Warwick, Coventry CV4 7AL, U.K.
}

(Received 8 April 1981; revised 23 June 1981)

Cellulose extracted from wheat straw, Avicel and CF11 cellulose powder contained $90 \%$ (w/w) glucose, whereas filter paper and carboxymethylcellulose contained $18 \%$ and $28 \%$ $(w / w)$ hemicelluloses, respectively. The straw cellulose was used as the sole carbon source to enrich for a mixed culture of micro-organisms in a stirred liquid medium and on a perfusion column containing glass beads. Amongst the micro-organisms isolated only fungi had cellulase activity and this activity was greatest in cultures of Cladosporium cladosporoides. The remainder of the community consisted of non-cellulolytic secondary organisms. The interactions of cellulolytic fungi with other micro-organisms found in the enrichment mixed culture are discussed.

\section{INTRODUCTION}

The degradation of cellulose by micro-organisms is a major component of the carbon and energy flux in soil. Lignocellulosic crop residues, such as cereal straw, provide the principal input of cellulose to arable soils (Lynch, 1979). The biodegradation of cellulose has important consequences for the cultivation of arable soils, since under conditions of restricted oxygen supply, microbial populations and metabolism change significantly with the result that phytotoxic concentrations of acetic acid accumulate (Lynch, 1977, 1978, 1980; Lynch \& Gunn, 1980; Lynch et al., 1980). Under aerobic conditions, plant growth can be promoted by the products of cellulolysis (Lynch, 1977), but the precise nature of the population changes is poorly understood.

Cellulose and hemicelluloses each account for about $40 \%(w / w)$ of straw and they are degraded at about equal rates and much more rapidly than the lignin component (about $14 \%$, w/w) under field conditions (Harper \& Lynch, 1981).

An understanding of the overall cellulolytic activity of pure or mixed microbial cultures depends on knowledge of the activity of the three groups of enzymes involved in cellulose degradation which act synergistically (Wood \& McCrae, 1978). Activity against Avicel, carboxymethylcellulose and cellobiose (for cellobiase) provides this information.

In the present study we have isolated the cellulose fraction of wheat (Triticum aestivum) straw and compared its purity with other sources of cellulose that are commonly used in degradation studies and enzyme assays. Straw-derived cellulose was used as the substrate in a stirred fermentation vessel and in a column containing glass beads to enrich and isolate aerobic cellulolytic micro-organisms from soil, and the intra- and extracellular cellulolytic activities of these isolates were investigated.

\section{METHODS}

Extraction and purification of cellulose from straw. Hammer-milled wheat straw $(100 \mathrm{~g})$ was heated at $75^{\circ} \mathrm{C}$ for $2 \mathrm{~h}$ with $10 \%(\mathrm{v} / \mathrm{v})$ acetic acid $(200 \mathrm{ml})$ and sodium chlorite $(60 \mathrm{~g})$ in distilled water $(3 \mathrm{l})$. The supernatant was then removed and replaced with a fresh solution, and the mixture was heated at $75^{\circ} \mathrm{C}$ for a further $2 \mathrm{~h}$. The 
resulting delignified straw was washed thoroughly and dried overnight at $60^{\circ} \mathrm{C}$. To remove the hemicellulose fraction, it was treated with $24 \%(\mathrm{w} / \mathrm{v})$ potassium hydroxide $(21)$ at $20^{\circ} \mathrm{C}$ for $2,4 \mathrm{or} 6 \mathrm{~h}$. It was then washed, neutralized with $5 \%(\mathrm{v} / \mathrm{v})$ acetic acid $(500 \mathrm{ml})$, rewashed with distilled water, dried and ball-milled (model no. 2 fixed speed, Pascall Engineering, Crawley, Sussex) for $5 \mathrm{~h}$.

Estimation of the purity of celluloses and cellobiose. The cellulose fraction produced by the above procedure and the following materials were analysed for sugar content: FMC Corporation Avicel PH101 (Honeywill \& Stein, Wallington, Surrey), BDH high viscosity carboxymethylcellulose sodium salt, cellobiose, Whatman CF 11 fibrous cellulose powder, and Whatman no. 1 ashless filter paper. Cellulose samples $(1 \mathrm{~g})$ were acid hydrolysed by adding sulphuric acid $(72 \%, w / w ; 15 \mathrm{ml})$ at $10^{\circ} \mathrm{C}$ and then maintained at $20^{\circ} \mathrm{C}$ in a water bath for $2 \mathrm{~h}$. Water $(560 \mathrm{ml})$ was then added to dilute the acid to $3 \%(\mathrm{w} / \mathrm{w})$, and the hydrolysate was boiled for $4 \mathrm{~h}$ and filtered immediately. The filtrate was neutralized with barium bicarbonate and the water was removed under low pressure on a rotary evaporator. The sugars were extracted from the residue into methanol, which was subsequently removed on a rotary evaporator. Rhamnose $(1 \mathrm{mg})$ was added as internal standard and the sugars were derivatized by the alditol acetate method and analysed by gas-liquid chromatography (Crowell \& Burnett, 1967).

The ash content of straw cellulose was measured by combustion in a furnace at $500^{\circ} \mathrm{C}$ and the $\mathrm{N}$ content was measured using a Carlo Erba elemental analyser (model 1106, Erba Science, Swindon, Wilts).

Enrichment and isolation of micro-organisms in closed cultures. The defined medium contained ( $\mathrm{g}^{-1}$, in distilled water): (a) straw cellulose treated with alkali for $4 \mathrm{~h}$ during extraction, 10 ; (b) $\mathrm{KH}_{2} \mathrm{PO}_{4}, 5.0$; (c) $\mathrm{Na}_{2} \mathrm{SO}_{4}$, 1.0: $\mathrm{MgSO}_{4} .7 \mathrm{H}_{2} \mathrm{O}, 0.25 ; \mathrm{FeSO}_{4} .7 \mathrm{H}_{2} \mathrm{O}, 0.1 ; \mathrm{CaCl}_{2}, 0.05 ; \mathrm{MnSO}_{4} .4 \mathrm{H}_{2} \mathrm{O}, 0.02 ; \mathrm{ZnSO}_{4} .7 \mathrm{H}_{2} \mathrm{O}, 0.02 ;$ $\mathrm{CuSO}_{4} .5 \mathrm{H}_{2} \mathrm{O}, 0.005 ; \mathrm{Na}_{2} \mathrm{MoO}_{4} .2 \mathrm{H}_{2} \mathrm{O}, 0.005 ; \mathrm{CoCl}_{2} .5 \mathrm{H}_{2} \mathrm{O}, 0.001 ; \mathrm{Na}_{2}$ EDTA $.2 \mathrm{H}_{2} \mathrm{O}, 0.6$; (d) $\mathrm{NH}_{4} \mathrm{Cl}$, either $1.5,0.31,0.15$ or 0.1 (to give medium $\mathrm{C}: \mathrm{N}$ ratios of $10: 1,50: 1,100: 1$ or $150: 1$ ). The $\mathrm{pH}$ of the buffer was adjusted to $6 \cdot 5$; components (a) to (d) were autoclaved separately and mixed aseptically.

The four media $(750 \mathrm{ml}$ each) of different nitrogen contents were added to vessels of a type 4/11 batch fermenter (L.H. Engineering, Stoke Poges, Bucks) and inoculated with a Lawford series clay soil ( $1 \mathrm{~g}$ ) in which straw residues had been decomposing for about 1 month. The cultures were stirred, aerated at $500 \mathrm{ml} \mathrm{min}^{-1}$ and maintained at $20^{\circ} \mathrm{C}$. Samples from the culture medium and from the walls of the vessels were removed at weekly intervals for $49 \mathrm{~d}$. Dilutions were made and added to tryptone soya agar, nutrient agar, malt extract agar, glucose yeast extract agar, cellulose agar (Bravery, 1968), sucrose nitrogen-free agar (Harper \& Lynch, 1979) and the enrichment medium with a $C: N$ ratio of $10: 1$ solidified with $1 \%(w / v)$ agar. The plates were incubated at $20^{\circ} \mathrm{C}$; individual colonies were isolated and repeatedly transferred until pure cultures were obtained.

Enrichment and isolation of micro-organisms using perfusion columns. A glass tube $(40 \mathrm{~cm} \times 7 \mathrm{~cm}$ i.d.) was filled with glass beads $(5 \mathrm{~mm}$ diam.). A reservoir $(2.5 \mathrm{l})$ was filled with the enrichment medium with a $\mathrm{C}: \mathrm{N}$ of ratio of $10: 1$. Soil $(1 \mathrm{~g})$ was distributed evenly amongst the glass beads and the medium was pumped through the column and continuously recirculated from the reservoir. The column was aerated at $400 \mathrm{ml} \mathrm{min} \mathrm{m}^{-1}$ and maintained at $20^{\circ} \mathrm{C}$. After $49 \mathrm{~d}$, the beads were removed from the column and samples from different depths and the liquid from the reservoir were incubated on the various media described above to isolate micro-organisms from the liquid medium.

Growth of isolates on media with different carbon sources. The isolates were inoculated on to agar media either with no carbon source or with straw cellulose, carboxymethylcellulose or glucose (each at $5 \mathrm{~g}^{-1}$ ). Medium A (Bravery, 1968) contained ( $\mathrm{g} \mathrm{I}^{-1}$, in distilled water): $\mathrm{KH}_{2} \mathrm{PO}_{4}, 1.0 ; \mathrm{KCl}, 0.5 ; \mathrm{MgSO}_{4} .7 \mathrm{H}_{2} \mathrm{O}, 0.2 ; \mathrm{CaCl}_{2}, 0.1$; thiamin. $\mathrm{HCl}, 0.001 ;\left(\mathrm{NH}_{4}\right)_{2} \mathrm{SO}_{4}, 0.5$. Medium B (Ayres et al., 1919) contained $\left(\mathrm{g} \mathrm{t}^{-1}\right.$, in distilled water): $\mathrm{NH}_{4} \mathrm{H}_{2} \mathrm{PO}_{4}, 1.0 ; \mathrm{KCl}, 0.2 ; \mathrm{MgSO}_{4} .7 \mathrm{H}_{2} \mathrm{O}, 0.2$. Medium $\mathrm{C}$ was the isolation medium described above. Growth was estimated visually.

Quantitative analysis of cellulase production. Isolates were grown in medium A $(20 \mathrm{ml})$ with purified straw cellulose at $5 \mathrm{~g} \mathrm{l}^{-1}$ contained in conical flasks $(250 \mathrm{ml})$ on a rotary shaker $\left(220 \mathrm{rev}\right.$. $\left.\mathrm{min}^{-1}\right)$ at $20^{\circ} \mathrm{C}$ for $14 \mathrm{~d}$. The cultures were membrane-filtered $(0.22 \mu \mathrm{m})$. The filtrate was stored frozen. The micro-organisms were washed with water $(5 \times 10 \mathrm{ml})$ until no cellulose was evident on the hyphae. They were then transferred to Universal bottles, distilled water was added $(10 \mathrm{ml})$ and they were stored frozen. Prior to use the samples were thawed and the organisms in the pellets were disrupted by sonication for four periods of $30 \mathrm{~s}$ while being cooled in an ice-bath.

The extracellular enzymes present in the filtrate and the intracellular enzymes from the disrupted cells were assayed by incubating samples $(1 \mathrm{ml})$ with $1 \%$ suspensions or solutions $(1 \mathrm{ml})$ of Avicel, carboxymethylcellulose or cellobiose in $0.05 \mathrm{M}$-citrate buffer, $\mathrm{pH} 5.0$, at $48^{\circ} \mathrm{C}$ for $30 \mathrm{~min}$ (with cellobiose as substrate) or $1 \mathrm{~h}$ (with Avicel or carboxymethylcellulose as substrate). An internal standard $(100 \mu \mathrm{l})$ of phenyl- $\beta$-D-glucopyranoside $(10.6 \mathrm{mg}$ $\mathrm{ml}^{-1}$. in pyridine) was added, and the sugars released by enzyme activity were derivatized as trimethylsilyl oximes and estimated by gas-liquid chromatography (Petersson, 1974).

\section{RES ULTS}

Purity of cellulose. The straw cellulose produced after $4 \mathrm{~h}$ treatment with alkali, to remove hemicelluloses, had a similar proportion of glucose to non-glucose residues as had Avicel and 
Table 1. Sugar content of different celluloses and cellobiose

\begin{tabular}{lcccc} 
Source of cellulose & \multicolumn{4}{c}{ Sugar content $(\%, w / w)$} \\
\cline { 2 - 5 } FMC Corporation Avicel PH101 & Arabinose & Galactose & Glucose & Xylose \\
BDH Carboxymethylcellulose & 2.5 & 2.5 & 90.0 & 5.0 \\
Cellobiose & 0 & 10.5 & 71.9 & 17.6 \\
Whatman CF11 fibrous cellulose powder & 0 & 0 & 100 & 0 \\
Whatman no. 1 ashless filter paper & 5.2 & 0 & 89.3 & 5.5 \\
Straw cellulose produced by KOH & 10.5 & 0 & 82.0 & 7.6 \\
treatment for: 2 h & & & & \\
$4 \mathrm{~h}$ & 3.0 & 0 & 86.0 & 10.9 \\
$6 \mathrm{~h}$ & 2.6 & 0 & 89.0 & 8.4 \\
& 2.4 & 0 & 89.4 & 8.2
\end{tabular}

CF11 cellulose, and this was greater than the proportion in filter paper and carboxymethylcellulose (Table 1). A further $2 \mathrm{~h}$ treatment with alkali did not increase the proportion of glucose in straw cellulose. The $\mathrm{N}$ content of the straw cellulose was less than $1 \mathrm{mg} \mathrm{g}^{-1}$ and the ash content was $14 \mathrm{mg} \mathrm{g}^{-1}$.

Isolation of micro-organisms. The stirred closed culture enrichment resulted in the isolation of five fungi, two yeasts and a bacterium (Table 2). These organisms were present at all C:N ratios tested. The bacterium was present in the free liquid whilst the fungi were isolated from the vessel walls. During the first $7 \mathrm{~d}$ there were about $1 \times 10^{10}$ viable organisms $\mathrm{ml}^{-1}$ but thereafter the number of viable organisms declined to about $1 \times 10^{9} \mathrm{ml}^{-1}$ for the succeeding $28 \mathrm{~d}$, irrespective of the $\mathrm{C}: \mathrm{N}$ ratio of the medium.

Isolations from the perfusion columns gave five fungi, two yeasts and two bacteria (Table 2), all different from those isolated from the stirred cultures. The column microflora varied according to depth, the fungi being found throughout, $B$. cereus only in the surface $5 \mathrm{~cm}, P$. maltophilia at $10-25 \mathrm{~cm}$ and the yeasts at $20-25 \mathrm{~cm}$.

Cellulolysis in agar plates. The fungi grew well and produced clearing zones on all media containing straw cellulose (Table 2). Some of the yeasts showed slight activity but the bacteria had none. All organisms grew when cellulose was replaced by carboxymethylcellulose or glucose. A few organisms showed slight growth even in the absence of an added carbon source, presumably on monomeric components in agar.

Quantitative analysis of cellulase activity. Large variations in cellulase activity were detected depending on the assay substrate and location of the activity (Table 3). Only the fungi, with the exception of Mucor hiemalis, showed positive cellulase activity in these assays and this was mainly extracellular. Generally, activity was greater against Avicel, but with Geotrichum candidum, activity was detected only on carboxymethylcellulose. Cladosporium cladosporoides produced the highest cellulase activity detected on both Avicel and carboxymethylcellulose. Only weak activity was found for any culture filtrate with cellobiose as the enzyme substrate. The intracellular cell extracts generally had greatest activity against cellobiose.

\section{DISCUSSION}

A source of variation in cellulase assays is the type of cellulose substrate used. Different forms of cellulose vary in the extent of their crystallinity (Rautela \& King, 1968), but the finding that filter paper and carboxymethylcellulose, both of which are frequently used for cellulase assays, contain up to $30 \%$ hemicelluloses is surprising. Even Avicel, cellulose powder and the freshly prepared straw cellulose contained $10 \%$ hemicelluloses.

Cultures of Trichoderma species are the normal sources of cellulase for industrial use. In this study two cellulolytic species of Trichoderma were isolated, but these did not produce the 


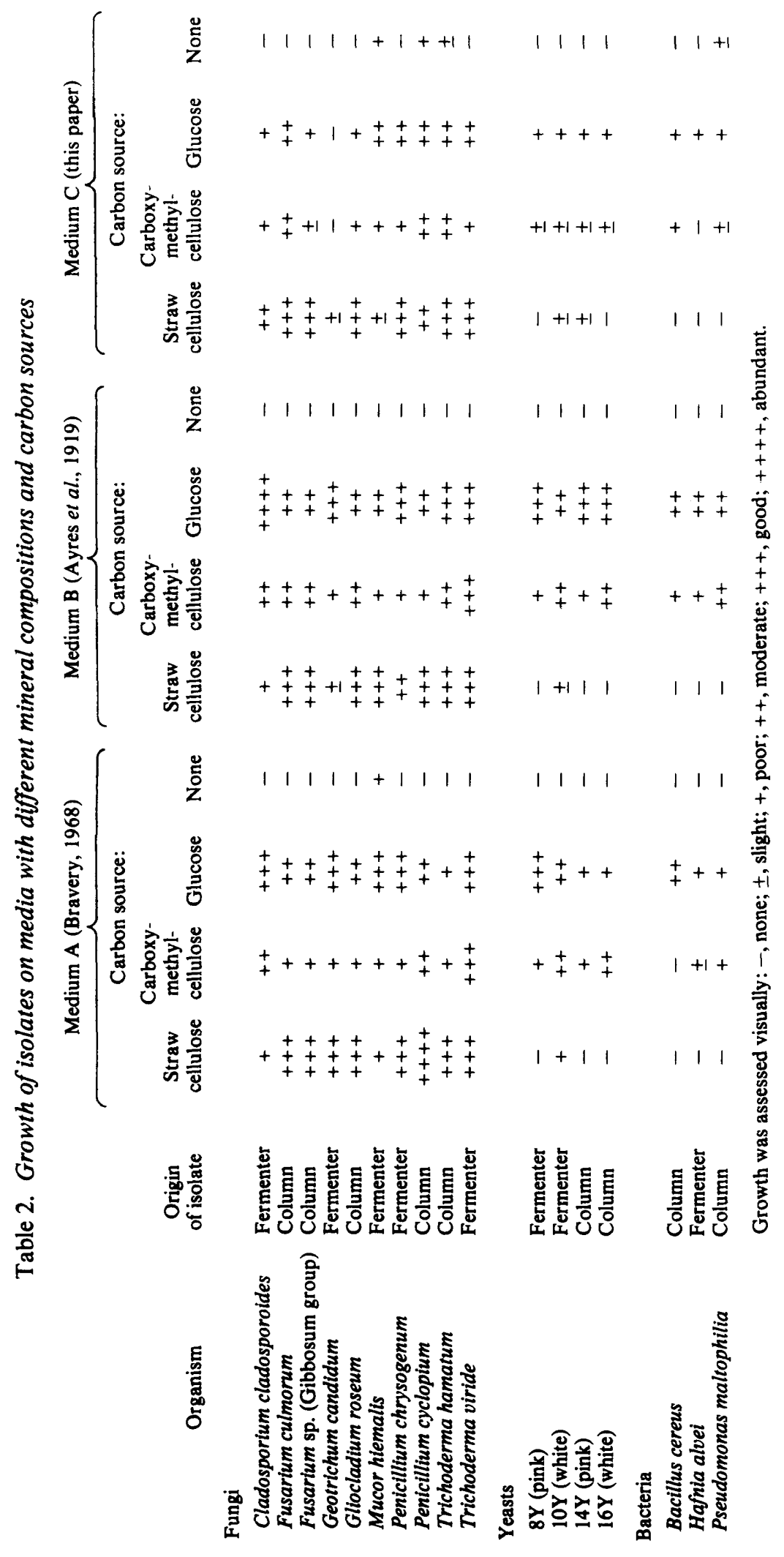


Table 3. Extracellular and intracellular cellulase activities of fungal isolates

\begin{tabular}{|c|c|c|c|c|c|c|}
\hline & \multicolumn{6}{|c|}{ Cellulase activity [mg glucose produced (g cell dry wt) ${ }^{-1} \mathrm{~h}^{-1}$ ] } \\
\hline & \multicolumn{3}{|c|}{ Activity in culture filtrates } & \multicolumn{3}{|c|}{ Activity in cell extracts } \\
\hline & & Substrate: & & & Substrate: & \\
\hline rganism & Avicel & $\begin{array}{c}\text { Carboxy- } \\
\text { methyl- } \\
\text { cellulose }\end{array}$ & Cellobiose & Avicel & $\begin{array}{c}\text { Carboxy- } \\
\text { methyl- } \\
\text { cellulose }\end{array}$ & Cellobiose \\
\hline ladosporoides & 18.40 & 8.48 & 0.24 & 0.24 & 0.52 & 12.24 \\
\hline orum & $2 \cdot 17$ & 0.42 & 0.14 & 0.57 & 0.42 & 18.92 \\
\hline (Gibbosum group) & 2.09 & 0.47 & 0.08 & 0.19 & 0.04 & 0.14 \\
\hline andidum & 0 & 3.00 & $6 \cdot 50$ & 0 & 0 & 0 \\
\hline eum & 0.36 & 0.01 & 0.02 & 0.22 & 0.02 & 9.46 \\
\hline 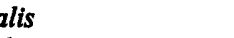 & 0 & 0 & 0 & 0 & 0 & 0 \\
\hline sogenum & 10.00 & 0.27 & 5.94 & 3.69 & 0.69 & $5 \cdot 30$ \\
\hline pium & 1.69 & 0.21 & 0.06 & 0.23 & 0.11 & 6.64 \\
\hline hamatum & 4.41 & 0.65 & 0.18 & 0.55 & 0.63 & $2 \cdot 30$ \\
\hline viride & 8.13 & 2.79 & 0.08 & 0.48 & 0.38 & $15 \cdot 52$ \\
\hline
\end{tabular}

greatest cellulase activities of the species isolated (at the time and temperature used for the assay). The quantitative cellulose assay provided some comparison of cellulolytic activity. The agar plate assays gave some confusing results depending on the medium used, and the quantitative assay would also be subject to this restriction. For example, Penicillium cyclopium grew much better on straw cellulose in medium $A$ than in medium C. Growth conditions would also presumably affect enzyme activity.

The two different isolation systems yielded a different population of cellulolytic fungi. The bacteria and yeasts which were simultaneously isolated were non-cellulolytic. It is possible that they may be members of stable communities (Slater \& Bull, 1978) with the fungi. Such interactions between micro-organisms might result in a more efficient overall cellulolysis, such as occurs in rumen cellulolysis (Lynch et al., 1979).

In the soil, community interactions are common. Our isolates were obtained from populations selected under forced aeration, whereas in naturally aerated soils, anaerobic microbial activity is widespread (Drew \& Lynch, 1980). In the absence of oxygen, anaerobic bacteria can be expected to contribute to the overall cellulolysis. Even if oxygen is present, as part of a community interaction aerobes may provide respiratory protection to the cellulolytic anaerobes (R. E. Hungate, personal communication).

We thank the Science Research Council for the award of a CASE studentship (J.A.B.), and the Commonwealth Mycological Institute and Torry Research Station for identifying the micro-organisms.

\section{REFERENCES}

Ayres, S. H., Rupp, P. \& Johnson, W. T. (1919). A study of the alkali-forming bacteria in milk. Bulletin of the United States Department of Agriculture, no. 782.

BRAVERY, A. F. (1968). Microbiological breakdown of cellulose in the presence of alternative carbon sources. Journal of the Science of Food and Agriculture 19, 133-135.

Crowell, E. P. \& BurnetT, B. R. (1967). Determination of the carbohydrate composition of wood pulp by gas chromatography of the alditol-acetates. Analytical Chemistry 39, 121-124.

Drew, M. C. \& LYNCH, J. M. (1980). Soil anaerobiosis, micro-organisms and root function. Annual Review of Plant Pathology 18, 37-67.

HARPER, S. H. T. \& LYNCH, J. M. (1979). Effects of Azotobacter chroococcum on barley seed germination and seedling development. Journal of General Microbiology 112, 45-51.

HARPER, S. H. T. \& LYNCH, J. M. (1981). The kinetics of straw decomposition in soil. Journal of Soil Science (in the Press).

LYNCH, J. M. (1977). Phytotoxicity of acetic acid produced in the anaerobic decomposition of wheat straw. Journal of Applied Bacteriology 42, 81-87.

LYNCH, J. M. (1978). Production and phytotoxicity of 
acetic acid in anaerobic soils containing plant residues. Soil Biology and Biochemistry 10, 131135.

LYNCH, J. M. (1979). Straw residues as substrates for growth and product formation by soil microorganisms. In Straw Decay and its Effect on Utilization and Disposal, pp. 47-55. Edited by E. Grossbard. Chichester: Wiley.

LYNCH, J. M. (1980). Effects of organic acids on the germination of seeds and growth of seedlings. Plant, Cell and Environment 3, 255-259.

LYNCH, J. M. \& GUNN, K. B. (1980). The use of the chemostat to study the decomposition of wheat straw in soil slurries. Journal of Soil Science 29, 551-556.

LyNCH, J. M., Fletcher, M. \& LATHAM, M. J. (1979). Biological interactions. In Microbial Ecology. A Conceptual Approach, pp. 171-187. Edited by J. M. Lynch \& N. J. Poole. Oxford: Blackwell Scientific Publications.

LynCh, J. M., GunN, K. B. \& Panting, L. M. (1980).
On the concentration of acetic acid in soil. Plant and Soil 56, 93-98.

Petersson, G. (1974). Gas chromatographic analysis of sugars and related hydroxy acids as acyclic oxime and ester trimethylsilyl derivatives. Carbohydrate Research 33, 47-61.

RauTELA, G. S. \& KING, K. W. (1968). Significance of the crystal structure of cellulose in the production and action of cellulase. Archives of Biochemistry and Biophysics 123, 589-601.

Slater, J. H. \& Bull, A. T. (1978). Interactions between microbial populations. In Companion to Microbiology, pp. 181-206. Edited by A. T. Bull \& P. M. Meadow. London: Longmans.

Wood, T. M. \& MCCrAe, S. I. (1978). The mechanism of cellulase action with particular reference to the $\mathrm{C}_{1}$ component. In Bioconversion of Cellulosic Substances into Energy, Chemicals and Microbial Protein, pp. 111-141. Edited by T. K. Ghose. Delhi, India: IIT. 